\title{
RELAPSES AFTER RESECTION FOR PULMONARY TUBERCULOSIS
}

\author{
BY \\ A. M. W. HEKKING \\ From the Sanatorium "Dekkerswald," Groesbeek, Netherlands
}

(RECEIVED FOR PUBLICATION JULY 30, 1956)

Pulmonary tuberculosis has always been notorious for its inherent tendency to relapse. As a rule the healing process from a tuberculous infection takes a slow course and a restitutio ad integrum is hardly to be expected. After a clinical cure there are practically always more or less extensive anatomical changes persisting in the tissues affected. These may easily constitute sources of later recurrences. The chances of relapse are also increased by the general character of the disease, which manifests itself in the fact that several parts of one organ or several organs can be affected at the same time. The chances of recurrence can likewise be increased by disturbances in the immunity relationships in the body and by emotional stress of social or psychic origin to which the former tuberculosis sufferer is exposed.

No method of treatment of tuberculosis, the various forms of collapse treatment included, has thus far succeeded in suppressing completely this tendency to relapse. The question now arises whether the introduction of pulmonary resections in the treatment of tuberculosis has, if not completely eliminated, at any rate markedly decreased, the danger of relapse. A superficial consideration might lead to the supposition that a pulmonary resection does reduce the risk of relapse, because in this operation grossly pathological parts of the lung are removed and these have the greatest chance of causing a relapse. In view of the generalized nature of tuberculosis we must accept that it is only rarely if ever possible to remove all tuberculous lung tissue, which holds true for those cases where all macroscopic lesions have disappeared. It is therefore not to be expected that no relapses would occur after pulmonary resection for tuberculosis. The fact that tuberculosis is a general disease means that pulmonary resection should always be regarded as a local treatment and a part of the general treatment. Hence we attribute value to a pre-operative and post-opera- tive rest course, under strict supervision and preferably in a sanatorium. Apart from some emergency indications, we believe that resection should only be carried out when the patient has been proved resistant against tuberculosis. This is shown by a normal temperature curve, a low E.S.R., and the absence of exudative components on the radiograph. To attain this condition a prolonged pre-operative treatment (at least of four to six months' duration), consisting of strict bed rest combined with tuberculostatics, will almost always be necessary. There is only sense in resection if it affords the possibility of removing those pathologically changed parts of the lung which cannot be cured by conservative treatment. This does not imply that it would be incorrect to leave no pathologically changed tissue in the same lung or in the opposite one during the operation. In this case one must be convinced that the remaining foci have sufficiently recovered, i.e., that they are largely fibrosed or calcified, so that the chances of relapse are minimized.

Even if these criteria have been adhered to in considering the indications for pulmonary resection, relapses still occur in a number of cases. For example, at a scientific meeting of the Union Internationale contre la Tuberculose, in Paris in July, 1955, relapse after pulmonary resection was reported by members from France, Belgium, Germany, Switzerland, and the Netherlands. Bérard, Arribéhaute, Germain, and Dumarest (1955) found $6.5 \%$ relapses in a series of 1,260 resections for pulmonary tuberculosis, Hirdes (1955) found 7.6\%, and Kraan (1955) $8.9 \%$. Before proceeding to a more detailed analysis of the various factors which might have had an influence on the occurrence of these relapses, we must define the meaning of the term "relapse" in the sense in which we use it. A relapse of a tuberculous process is a renewal of the tuberculous pulmonary abnormalities, usually 
combined with newly positive sputum, fever, and increased E.S.R., after a period during which the previously treated patient has recovered and been able to work.

We consider our patients sufficiently clinically cured when, after resection, they have finished the whole post-operative sanatorium course, including occupational therapy. In our sanatorium an average of five to seven months after the operation is necessary to reach this stage. If in the following pages the term "relapse" is used, this is exclusive of the complications or reactivations which have arisen directly after the resection or a short time afterwards. In order to obtain a correct understanding of the problem of these relapses, it is necessary to determine, in addition to their frequency, the influence which various factors may have exerted on their development.

The anamnestic data should, for example, be taken into consideration, in addition to age and sex. These data may inform us about the strength of the patient's powers of defence against the disease; in other words, whether the history includes one or more relapses, and, if so, which forms of treatment the patient has undergone before, be it conservative or more active such as collapse therapy. In assessing the relapses both the indications for resection and the type of resection used should be taken into account, attention also being given to the patient's psychic structure and his social circumstances after the cure. It should further be verified whether there is any connexion between the development of the relapse and the tuberculous abnormalities which may have persisted in one of the lungs after the resection; in this case it must be known whether the reactivation took place on the resected side or on the opposite side.

The present study deals with 525 total or partial pulmonary resections, carried out by J. L. Goemans in the sanatorium "Dekkerswald " from March, 1949, to December 31, 1953, inclusive. In this way a homogeneous series was obtained, as the same team dealt with the indications for operation, the pre-treatment and after-care and the operations. In the autumn of 1955 an extensive investigation of the results of this treatment was carried out by means of a questionnaire. Sufficient data on the further course and the present condition were obtained from all 525 patients, either from themselves and/or from their attending physician and/or from the tuberculosis dispensary. The period of observation therefore ranges from a maximum of six and a half years to a minimum of about two years after the operation.

\section{RESULTS}

Table I shows the relationship between the number of relapses and the post-operative early complications not accompanied by a manifest reactivation of a pulmonary process. Table I also shows that we had a total of 32 fatal cases. Of these $26(5 \%)$ died as a result of the operation as such or from tuberculous complications or disseminations, while six patients died afterwards from intercurrent disease.

TABLE I

TOTAL NUMBER OF RESECTIONS (MARCH, 1949DECEMBER 31, 1953) 525

State on January 1, 1956

Primary permanent cures Died, remained ill, or relapsed $422(80 \%)$ $103(20 \%)$

$\begin{aligned} & \text { Complications and dis- } \\ & \text { seminations immediate- } \\ & \text { ly or shortly after } \\ & \text { resection }\end{aligned}$
$\begin{aligned} & \text { Late tuberculous } \\ & \text { complications } \\ & \text { without fresh } \\ & \text { pulmonary foci }\end{aligned}$

Of the 525 (Table II) patients who had undergone a pulmonary resection, 422 have remained healthy and fit for work for two to six years postoperatively, while another 44 recovered after complications or relapses. On January 1, 1956, a total of 466 patients (or about $89 \%$ ) were considered cured. Thirty-two patients were still under treatment. The number of relapses as defined above was $39(7.4 \%)$.

TABLE II

STATE ON JANUARY 1, 1956, of 525 CASES WITH RESECTIONS PERFORMED BETWEEN MARCH, 1949, AND DECEMBER 31, 1953

Cured: $\left.\begin{array}{llllllr}\text { Primary } & \ldots & . & \ldots & \ldots & \ldots & 422 \\ \text { Secondary } & . & . . & . . & . . & . & 39\end{array}\right\}(88.8 \%)$

Died: $\begin{aligned} & \text { Operative and tuberculous complications .. } \\ & \text { Intercurrent .. }\end{aligned}$

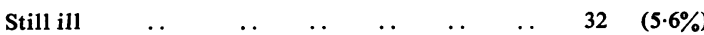

RelaPSE AND SEX.-Of the 525 resections, 193 were carried out in men and 332 in women (Table III). This is approximately the same ratio as that of the men and women who were under treatment in the sanatorium during that time. The number of relapses among the men was 18 or $9.4 \%$, among the women 21 or $6.3 \%$.

TABLE III RELAPSES AND SEX

\begin{tabular}{|c|c|c|c|c|}
\hline Sex & & $\begin{array}{l}\text { No. of } \\
\text { Resections }\end{array}$ & $\begin{array}{l}\text { No. of } \\
\text { Relapses }\end{array}$ & $\%$ \\
\hline $\begin{array}{l}\text { Males } \ldots \\
\text { Females . }\end{array}$ & $\cdots$ & $\begin{array}{l}193 \\
332\end{array}$ & $\begin{array}{l}18 \\
21\end{array}$ & $\begin{array}{l}9 \cdot 4 \\
6 \cdot 3\end{array}$ \\
\hline Total & $\ldots$ & 525 & 39 & $7 \cdot 4$ \\
\hline
\end{tabular}


Relapse and Age.-The number of relapses is evenly distributed over all age groups (Table IV). We did not find in particular that the percentage of relapses would be higher in resections in older patients.

TABLE IV

RELAPSES AND AGE

\begin{tabular}{c|c|c}
\hline Age (Years) & No. of Resections & No. of Relapses \\
\hline $0-10$ & 2 & $0(0 \%)$ \\
$11-20$ & 71 & $5(7 \%)$ \\
$21-30$ & 248 & $20(8 \%)$ \\
$31-40$ & 133 & $9(6 \%)$ \\
$41-50$ & 54 & $3(5 \cdot 5 \%)$ \\
$51-60$ & 15 & $1(6.6 \%)$ \\
$61-70$ & 2 & 1 \\
\hline Total & 525 & $39(7 \cdot 4 \%)$ \\
\hline
\end{tabular}

RelaPse AND Constitution.-The past history of these patients shows that 244 resections were carried out during the first period of the disease. Thirteen of these patients $(5.3 \%)$ have had a postoperative relapse. Twenty-six $(9 \%)$ post-operative relapses were observed after the 281 resections in patients who had had one or more previous relapses. We believe that the conclusion is justified that persons who have shown a decreased resistance against tuberculosis run a greater risk of relapsing also after resection (Table V).

TABLE V

RELAPSES AND CONSTITUTION

\begin{tabular}{|c|c|c|c|}
\hline $\begin{array}{l}\text { No. of Relapses } \\
\text { before Resection }\end{array}$ & & $\begin{array}{c}\text { No. of } \\
\text { Resections }\end{array}$ & $\begin{array}{l}\text { No. of Relapses } \\
\text { after Resection }\end{array}$ \\
\hline $\begin{array}{l}\text { None } \\
\text { One or more }\end{array}$ & $\because$. & $\begin{array}{l}244 \\
281\end{array}$ & $\begin{array}{l}13(5 \cdot 3 \%) \\
26(9 \%)\end{array}$ \\
\hline Total & $\therefore$ & 525 & $39(7 \cdot 4 \%)$ \\
\hline
\end{tabular}

Relapse and Time Elapsed Since Resection. -When the number of relapses observed is classified according to the years in which the resection took place (Table VI), the greatest number of relapses proves to be in the patients operated upon in the years 1950 and 1951. To study this more

TABLE VI

RESECTIONS CLASSIFIED ACCORDING TO YEAR OF PERFORMANCE

\begin{tabular}{c|c|c}
\hline $\begin{array}{c}\text { Year of } \\
\text { Resection }\end{array}$ & $\begin{array}{c}\text { No. of } \\
\text { Resections }\end{array}$ & $\begin{array}{c}\text { No. of Relapses } \\
\text { on Jan. 1, 1956 }\end{array}$ \\
\hline 1949 & 32 & 1 \\
1950 & 90 & 14 \\
1951 & 143 & 15 \\
1952 & 129 & 7 \\
1953 & 131 & 2 \\
\hline Total & 525 & 39 \\
\hline
\end{tabular}

closely, Table VII gives an analysis of the lapse of time between the operation and the relapse. As only those relapses are included which occurred after the termination of the after-treatment in the sanatorium, this analysis begins six months after the resection. Eighty per cent. of the relapses

TABLE VII

RELAPSE RATE ACCORDING TO YEAR OF RESECTION

\begin{tabular}{c|c}
\hline $\begin{array}{c}\text { Years after Resection } \\
\text { of Relapse }\end{array}$ & $\begin{array}{c}\text { No. of } \\
\text { Relapses }\end{array}$ \\
\hline${ }^{\frac{1}{2}-1}$ & 2 \\
$1-2$ & 18 \\
$2-3$ & 11 \\
$3-4$ & 6 \\
$4-6$ & 2 \\
\hline
\end{tabular}

prove to have occurred between one and three years after the resection. If the data from Tables VI and VII are combined, as is done in Table VIII, observation times longer than three years show only a slight increase of the relapse rate in the patients from the years 1949-50 and 1951. This may-with some reserve-lead to the conclusion that the total number of relapses of 1952 and probably also of 1953 will remain much lower than

TABLE VIII

COMBINED DATA OF TABLES VI AND VII

\begin{tabular}{|c|c|c|c|c|c|c|c|}
\hline \multirow{2}{*}{$\begin{array}{c}\text { Year of } \\
\text { Resection }\end{array}$} & \multirow{2}{*}{$\begin{array}{l}\text { No. of } \\
\text { Resections }\end{array}$} & \multicolumn{6}{|c|}{$\begin{array}{c}\text { No. of Relapses in Various Years } \\
\text { after Resection }\end{array}$} \\
\hline & & $\frac{1}{2}-1 \mathrm{yr}$. & |1-2 yr. & 2-3 yr. & $3-4$ yr. & . $4-6 \mathrm{yr}$. & Total \\
\hline $\begin{array}{l}1949 \\
1950 \\
1951 \\
1952 \\
1953\end{array}$ & $\begin{array}{r}32 \\
90 \\
143 \\
129 \\
131\end{array}$ & $\begin{array}{l}0 \\
1 \\
1 \\
0 \\
0\end{array}$ & $\begin{array}{l}0 \\
5 \\
8 \\
3 \\
2\end{array}$ & $\begin{array}{l}1 \\
5 \\
3 \\
2 \\
0\end{array}$ & $\begin{array}{l}0 \\
2 \\
2 \\
2\end{array}$ & $\begin{array}{l}0 \\
1 \\
1\end{array}$ & $\begin{array}{r}1 \\
14 \\
15 \\
7 \\
2\end{array}$ \\
\hline Total & 525 & 2 & 18 & 11 & 6 & 2 & 39 \\
\hline
\end{tabular}

that of the years 1950 and 1951. A possible explanation may be that in the first years of our resection treatment the cases were in general of a more serious nature than in the following years.

Relapse and TyPe of Resection.-A consideration of the relapses in connexion with the various types of resection (Table IX) shows that

TABLE IX

RELAPSE AND TYPE OF RESECTION

\begin{tabular}{|c|c|c|}
\hline $\begin{array}{c}\text { Type of } \\
\text { Resection }\end{array}$ & $\begin{array}{l}\text { No. of } \\
\text { Resections }\end{array}$ & $\begin{array}{l}\text { No. of } \\
\text { Relapses }\end{array}$ \\
\hline $\begin{array}{lccc}\begin{array}{l}\text { Pneumonectomy } \\
\text { Lobectomy }\end{array} & \ldots & \ldots & \ldots \\
\text { Lobectomy + segmental resection. } \\
\text { Segmental resection } & \ldots & . .\end{array}$ & $\begin{array}{r}139 \\
235 \\
57 \\
94\end{array}$ & $\begin{array}{l}13(9 \cdot 3 \%) \\
15(6.4 \%) \\
5(8 \cdot 8 \%) \\
6(5 \cdot 3 \%)\end{array}$ \\
\hline
\end{tabular}


the percentages of relapses were as follows: After pneumonectomy 9.3\%, after lobectomy $6.4 \%$, after lobectomy combined with segmental resection $8.8 \%$, and after a segmental resection $5.3 \%$. There is no statistical difference between the relapse rates for the various types of resection. No correlation can be demonstrated between the occurrence of relapses and the extent of the resection.

Relapse AND Stretching OF Remaining Pulmonary Tissue.-Although Table IX does not give evidence that relapses would be promoted by stretching of the spared parts of the lung, a study of Table $\mathrm{X}$ might lead to the opposite opinion. Table $X$ shows that 21 out of the 26 relapses after partial resections occurred on the side of the resection, i.e., in the site where the greatest degree of stretching of remaining parts of the lung was to be expected. Also in order to study this problem more closely we carried out physical, radiological, and functional investigation of 50 successive cases of pneumonectomy on an average four

TABLE $X$

RELAPSE AND STRETCHING OF PULMONARY TISSUE

\begin{tabular}{|c|c|c|c|}
\hline \multirow{2}{*}{$\begin{array}{l}\text { Kind of Partial } \\
\text { Resection }\end{array}$} & \multirow{2}{*}{$\begin{array}{l}\text { No. of } \\
\text { Resections }\end{array}$} & \multicolumn{2}{|c|}{$\begin{array}{l}\text { No. of Relapses } \\
\text { after Resection }\end{array}$} \\
\hline & & Homolateral & Contralateral \\
\hline $\begin{array}{l}\text { Lobectomy } \\
\text { Lobectomy +segmental } \\
\text { resection } \\
\text { Segmental resection } \quad \ldots\end{array}$ & $\begin{array}{r}235 \\
57 \\
94\end{array}$ & $\begin{array}{r}12 \\
5 \\
4\end{array}$ & $\begin{array}{l}3 \\
0 \\
2\end{array}$ \\
\hline Total .. & 525 & $21(5.4 \%)$ & $5(1 \cdot 3 \%)$ \\
\hline
\end{tabular}

years after the resection. The complete results of this study will be reported in a subsequent article. For the present problem it is sufficient to mention that there were four relapses among the series of 50 pneumonectomies, and that in these four cases the stretching of the spared parts of the lung was not very severe, both in a radiological and functional respect. This contrasts with what we found in the majority of patients in this last series in whom no relapses occurred later on, namely a considerable to maximum stretching of the remaining lung with a markedly increased residue. This investigation did not give us any reasons either to assume that very severe stretching of the remaining parts of the lung promotes relapse.

Relapse and Nature of Resected Process.Eleven relapses were found among the 231 noncavitational processes, i.e., $4.7 \%$, and 28 or $9.5 \%$ relapses among 294 cavitational processes (Table $\mathrm{XI}$. Even though the last-mentioned percentage cannot yet be called alarmingly high, it should still be kept in mind when considering an indication for resection therapy in a case of cavernous pulmonary tuberculosis.

TABLE XI

RELAPSE AND NATURE OF LESION

\begin{tabular}{|c|c|c|}
\hline Indication & $\begin{array}{c}\text { No. of } \\
\text { Resections }\end{array}$ & $\begin{array}{l}\text { No. of Relapses } \\
\text { on Jan. } 1,1956\end{array}$ \\
\hline $\begin{array}{l}\text { Primary pulmonary } \\
\text { tuberculosis } \\
\begin{array}{l}\text { Bronchostenosis } \\
\text { Caseous-fibrous foci }\end{array} \\
\begin{array}{l}\text { Tuberculomas } \\
\text { Drowned cavities }\end{array} \\
\begin{array}{l}\text { Localized cavitational } \\
\text { process }\end{array} \\
\begin{array}{l}\text { Extensive cavitational } \\
\text { changes }\end{array} \\
\begin{array}{l}\text { Destroyed lung } \\
\text { Des }\end{array}\end{array}$ & $\begin{array}{r}15 \\
63 \\
135 \\
18 \\
12 \\
87 \\
162 \\
33\end{array}$ & $\left.\begin{array}{rl}0 & (0 \%) \\
2 & (2.3 \%) \\
9 & (6.6 \%) \\
0 & (0 \% \%)\end{array}\right\} \begin{array}{l}\text { On } 231 \text { non-cavita- } \\
\text { tional processes } 11 \\
\text { relapses }(4.7 \%)\end{array}$ \\
\hline Total & 525 & $39(7 \cdot 4 \%)$ \\
\hline
\end{tabular}

TABLE XII

RELAPSE AND PRE-OPERATIVE SPUTUM

\begin{tabular}{|c|c|c|c|}
\hline $\begin{array}{l}\text { State of } \\
\text { Sputum }\end{array}$ & & $\begin{array}{l}\text { No. of } \\
\text { Resections }\end{array}$ & $\begin{array}{c}\text { No. of } \\
\text { Relapses }\end{array}$ \\
\hline $\begin{array}{c}\text { Negative sputum } \\
\text { Positive culture .. } \\
\text {,, sputum .. }\end{array}$ & $\begin{array}{l}\cdots \\
\cdots\end{array}$ & $\begin{array}{r}77 \\
199 \\
249\end{array}$ & $\begin{array}{l}2(2.6 \%) \\
12(6.0 \%) \\
25(10.0 \%)\end{array}$ \\
\hline Total .. & . & 525 & $39(7 \cdot 4 \%)$ \\
\hline
\end{tabular}

Table XII once more shows that the chance of relapse also increases in accordance with the severity and activity of the resected process. The number of relapses is here classified according to the degree of positive sputum before the operation. There is a difference between the relapse rates in the three different groups, negative sputum, positive culture, and microscopically positive sputum, namely $2.6,6$, and $10 \%$.

Relapse and Spared Pathologically Changed Pulmonary Tissue in Partial Pulmonary RESECTIONS.-A consideration of the number of relapses after partial pulmonary resections in patients with and without residual tuberculous foci in the remaining lungs or parts of lung demonstrated a difference in the relapse rates in favour of the group without residual foci (Table XIII).

TABLE XIII

RELAPSE AND SPARED PATHOLOGICALLY CHANGED PULMONARY TISSUE IN PARTIAL PULMONARY RESECTIONS

\begin{tabular}{|c|c|c|}
\hline Residual Foci & Sites of Residual Foci & No. of Relapses \\
\hline $\begin{array}{l}195 \text { cases without } \\
\text { residual foci }\end{array}$ & & $7(3.6 \%)$ \\
\hline $\begin{array}{l}191 \text { cases with resi- } \\
\text { dual foci }\end{array}$ & $\left\{\begin{array}{lr}\text { Homolateral } & 23 \\
\text { Contralateral } & 150 \\
\text { Bilateral } & 18\end{array}\right.$ & $\left.\begin{array}{l}4 \\
8 \\
7\end{array}\right\} 19(9 \cdot 9 \%)$ \\
\hline
\end{tabular}


The following figures show, however, that it is premature to draw the conclusion that all the residual pulmonary foci are the cause of the relapses.

This study deals with 386 partial pulmonary resections (lobectomies and segmental resections). After these partial resections pulmonary tissue is still present in 386 right and 386 left hemothoraces. In 563 of these 772 intact or by the operation partially reduced right and left lungs, no palpable or radiologically visible pathologically changed lung tissue was present after the resection, while more or less extensive tuberculous changes, usually of a fibrocaseous nature, could still be found in 209 lungs. In the 568 lungs without clear pathological changes 15 relapses occurred, i.e., $2.6 \%$, while 11 relapses were observed in the 209 lungs with tuberculous changes, i.e., 5.2\%. These differences are statistically not significant, which means that, at any rate for our material, it has not been proved that relapses develop preferably in those parts of the lungs in which pathologically changed pulmonary tissue has been left behind after the resection.

\section{Discussion AND ConClusions}

We did not enter in detail into the problem whether relapses after pulmonary resections for tuberculosis are of exogenous or endogenous origin. Our opinion, also based on the arguments given by Bronkhorst (1954) for the endogenous pathogenesis of pulmonary tuberculosis, is that these relapses are also practically all of endogenous origin. This opinion has strengthened our conviction that post-operative after-care of sufficiently long duration is necessary to minimize the incidence of relapses. The relapse rate is a decisive factor in the evaluation of the results of resection treatment in pulmonary tuberculosis. The risk of relapse still exists years after the resection, because of the nature of the disease.

In order to obtain an understanding of the frequency of these relapses, a number of resections and long post-operative observation periods are necessary. We believe that we have fulfilled these criteria with our 525 total or partial pulmonary resections with a follow-up period of maximally six years and minimally two years. This investigation shows that there were $7.4 \%$ relapses after 525 resections with an observation time of two to six years ; this figure corresponds with the percentages so far mentioned in the literature. An investigation into the relapse problem in tuberculosis, carried out by the Stichting Nederlandse Sanatorium Verzekering (Foundation for Sanatorium
Insurance in the Netherlands) shows, for example, that out of the 24,156 patients treated in the Dutch sanatoria in the years $1946-51$ a total of 3,154 or $13 \%$ relapsed in the period 1951-52-53. Ninetyfour per cent. of these patients had been treated conservatively or had undergone some form of collapse treatment. The follow-up period of these patients, with a relapse rate of $13 \%$, was practically the same as in our cases, in which the relapse rate was $7.4 \%$. The difference in these relapse percentages is significant, hence the conclusion is warranted that application of resection therapy instead of collapse therapy decreases the incidence of relapses. This is even more evident if it is realized that the first-mentioned group of 24,156 patients also contains a number of mild cases, while these are practically absent in our resection group. A closer analysis of the relapses in our patients after resection showed that resection of cavitary processes and resection of a more or less active process increase the chance of relapse. It seems also probable that patients who had already suffered one or more relapses pre-operatively run a greater risk of relapsing again after the resection.

It was impossible to find any influence of sex and age on the occurrence of relapses.

No cause was found for the fact that the percentage of relapses was highest after the resections carried out in the years 1950 and 1951. Neither could it be demonstrated that stretching of the remaining parts of the lung increased the chance of relapse. Nor was it clear that the relapses preferably originated in the pulmonary foci left behind after the resection in the homolateral or contralateral lung.

Seventy per cent. of the relapses, with an observation time of at least six years, occurred between one and three years after the operation. Supplementary investigations dealing with even greater numbers of patients and longer observation times can only decide whether this observation is a fortuitous one or whether the chance of relapse is indeed considerably reduced after the third year. This is of course of great prognostic importance in resection treatment.

\section{SUMMARY}

After a brief introduction a short survey is given of the results of resection treatment in 525 cases from pulmonary tuberculosis with a followup period of two to six years : $88.8 \%$ proved to be cured and were to be regarded as fit for work ; $5.6 \%$ were still under treatment; and $5.6 \%$ had died. The number of relapses observed $(7.4 \%)$ 
is subjected to a more detailed analysis. The conclusion is reached that the relapse rate has decreased since the introduction of pulmonary resection therapy. The chance of the development of relapses after pulmonary resections is increased by resection of cavitational processes, by resection in an active stage, and by resection in patients who have shown a low resistance against tuberculosis.
No clear influence on the development of relapses was proved for all other factors investigated.

\section{REFERENCES}

Bérard, M., Arribéhaute, R., Germain, J., and Dumarest, J. (1955). Rev. Tuberc. (Paris), 19, 511.

Bronkhorst, W. (1954). Geneesk. Bl., 46, 51.

Hirdes, J. J. (1955). Acta phtisiol. (Paris) (abstract), 4, No. 20, p. 24.

Kraan, J. K. (1955). Ibid. (abstract), 4, No. 20, p. 26. 